\title{
Research on the use of dehydrated whole maize plant in the feed of growing rabbits
}

\author{
Maria-Teresa AUXILIA, G. MASOERO \\ Istituto Sperimentale per la Zootecnia \\ Sezione Operativa Periferica. V. Pianezza II5, Torino toI5I (Italy)
}

Pelleted feeds containing o p. 100 or $20 \mathrm{p}$. Ioo or $4^{\circ} \mathrm{p}$. 100 dried whole-crop maize at the wax stage were given to growing rabbits.

A rearing trial was carried out in $5^{2}$ rabbits weaned at 28 days of age and slaughtered at 84 .

The average daily gain was quite similar in the three groups, while the voluntary intake was increased and the feed efficiency was reduced with dried maize at $4^{\circ} \mathrm{p}$. 100 .

The digestibility coefficients of nutrients and fibrous components of polysaccharides in the three diets during three periods between $4 \mathrm{I}$ and the $7 \mathrm{o}$ th days of age were tested.

The digestibility coefficients increased during the trial, but significantly until 60 days of age.

\section{Utilization of dehydrated whole maize plant for rabbits}

\author{
Madeleine SEROUX ( $\left.{ }^{(}\right)$, Y. FRANCK $\left({ }^{(2)}\right.$, P. MERCIER $\left({ }^{3}\right)$
}

(I) ITCF, Station Expérimentale, Boigneville, 9I72o Maisse (France).

(2) ITAVI, Service Technique, 28, rue du Rocher, 75008 Paris (France).

(3) UFAC, Service Cunicole, $9545^{\circ}$ Vigny (France).

Four trials were made to study dehydrated whole maize plant as crude fibre source in the diets of fattening rabbits.

Mature maize was incorporated into the diet at three levels: $30,5^{\circ}$ and $70 \mathrm{p}$. 10o. Furthermore (except in one trial) two stages of harvest were compared, hard dough stage versus mature at the level of $50 \mathrm{p}$. Ioo of the diet.

Crude protein and crude fibre contents of the feeds were $\mathrm{I}_{5}-\mathrm{I} 6 \mathrm{p}$. 100 and $\mathrm{I}_{4}-\mathrm{I} 5 \mathrm{p}$. roo. Neither the level of maize in the diet nor its stage of harvest affected the average daily gain.

A high proportion of maize at the latest harvest slightly reduced the feed consumption and accordingly the efficiency was improved.

Carcass yield was not motified.

\section{Utilization of dehydrated beet pulp for growing rabbits}

\author{
Y. FRANCK (1), Madeleine SEROUX (2)
}

(I) ITAVI, 28, wue du Rocher, 75008 Paris (France).

(2) ITCF, Boigneville, 9I70o Maisse (France).

Two trials were made to study the use of dehydrated sugar beet pulp in fattening rabbits (incorporation levels : $0-10-20-30$ p. I0o).

In the experimental conditions, and particularly with formulas including i6 $\mathrm{p}$. Ioo of Weende cellulose, no effect of high pulp levels on mortality was noticed. 